\title{
Energy Planning and Energy Efficiency in Smart City Areas
}

\author{
Yury R. Nurulin ${ }^{1}$, Inga $V$. Skvortsova ${ }^{1}$, Olga A. Kalchenko ${ }^{1, *}$ \\ ${ }^{1}$ Peter the Great Saint-Petersburg Polytechnic University, 29 Polytechnicheskaya, Saint-Petersburg, \\ 195251, Russia
}

\begin{abstract}
The main value added of the approach, which is considered in this paper, is the joint development of an innovative concept for energy improvement city's areas, as well as methods and tools for its implementation. A new coordinated approach to energy planning and implementation at the district level within the framework of the concept of smart cities contributes to the efforts of consumers to improve energy efficiency. The research focuses on energy efficiency for existing built-up urban structures. They represent a large part of the built environment of European cities and face significant, often urgent energy challenges.

Key words: smart city, energy planning, energy efficiency, strategy
\end{abstract}

\section{Introduction}

For the last decade there has been a significant increase of interest in research and innovation the field of integration of information and communication technologies (ICT) for the management of urban property. Reflecting this interest is the Smart City concept that are designed to improve the level of comfort and quality of life in cities, reduce costs and resource consumption through the extensive use of ICT. This concept is a logical development of the sustainable development goals (SDGs), outlined in The United Nations report "Our Common Future" [1].

At the same time models and methods of energy planning applied by local and regional government bodies do not provide a comprehensive approach that could reduce the fragmentation of particular sectors of the city's energy economy and maximize the energy saving potential in urban areas. The study has been done in frame of CBC ENPI project EFEM shows that efforts to develop strategies that integrate the behavior of all key participants in the energy supply and consumption system are not sufficient [2]. This is due to the lack of cooperation between local and regional government authorities, energy companies and end-users of energy resources. In addition, there are no tools for understanding the motives for behavior and analyzing barriers to the adoption of effective management decisions by end users that can provide direct information exchange of consumers with energy suppliers and actively participate in strategic energy planning [3].

\footnotetext{
* Corresponding author: o.kaltchenko@mail.ru
} 


\section{Literature review}

City areas are becoming "smarter," as governments, businesses, and communities increasingly rely on technology to overcome the challenges from rapid urbanization. Energy efficiency and the use of renewable energy are intimately linked with questions of energy security and energy supply and thus to sustainable development.

Sussman argues that local governments can have a positive impact on global warming by utilizing measures to foster energy efficiency and renewable energy use in government operations and by the general population [4].

Sustainable development cannot and must not be enacted top-down. A healthy balance between "bottom-up" and "top-down" is required to reach. "Think globally, act locally" may be a hackneyed phrase but it still resonates as a truth. Municipalities can have a substantial impact just by changing their own operations.

The transition towards renewable and sustainable energy is being accompanied by a transformation of communities and areas. Van Der Schoor and Scholtens investigated into the local community level towards realizing these ambitions from a social perspective [5].

Nilsson and Mårtensson, Palm studied energy systems in Swedish municipalities. Their analysis examined how municipalities promote oil reduction, efficient energy use, and the use of renewable energy $[6,7]$. Brandoni and Polonara showed on the Italian example, that the site-specific nature of renewable sources, the need to involve citizens in the energyplanning process and the perspective of local governments, who are the first governmental stakeholders involved in the implementation of energy-saving initiatives, had emphasised the strategic role played by municipalities in the energy-planning process [8].

\section{The problem definition}

The above challenges are reflected in the Strategy of economic and social development of St. Petersburg until 2030 that is aimed to provide stable improvement of life quality of citizens and to increase global competitiveness of St. Petersburg based on strategic priorities of Russian Federation, sustainable economic growth and use of results of innovation and technologic industries [9]. Achievement of the general objective is possible on the basis of active managerial influence on the leading sectors of economic complex and social sphere. This implies the need for a coordinated and organized work of local and regional authorities, public property owners, municipalities, as well as appropriate participation of business, science institutions, public organizations and citizens of St. Petersburg. The system of state and municipal management at the regional level should be aimed at creating incentives for the implementation of strategic planning and budgeting tools, focused on the result - improving the level and quality of life. Improving urban development, providing sustainable economic growth, ensuring effective governance and civil society development, human capital development - are strategic directions of St. Petersburg.

Any strategy is effective only in conjunction with the methods and plans for its implementation. In this regard the research is needed to improve the energy efficiency of cities by developing, piloting and disseminating innovative approaches and tools for integrated planning and energy use at the urban level. In these studies, the focus of research should be shifted from an analysis of individual technical or organizational decisions in relation to individual buildings to form a holistic system perspective on energy efficiency and energy consumption. New approaches and tools should be developed for the interaction of local and regional public authorities with end-users of energy resources in the planning and implementation of energy efficiency decisions, which will allow using the synergistic 
effect to reduce the fragmentation of the energy consumption system at the level of urban areas, synergies at the district level and reducing fragmentation of sectors [10].

\section{Materials and Methods}

The system approach to the energy planning and energy efficiency in smart city areas opens energy planning to new actors to develop and implement more effective energy efficiency solutions, exploit synergies on district level and reduce sectoral fragmentation [11, 12].

Main outputs of the project aimed on realisation of above strategy will be as follows:

- the concept of integrated strategic approach to cooperative energy efficiency planning on district level;

- the guidance on cooperative energy planning on district level, that describes barriers and factors of success;

- the process model for the cooperation of local and regional authorities, energy utilities and public property owners in energy efficiency implementation on district level;

- new ICT-based tools for involving citizens and property users in energy planning.

\section{Proposed solution for the problem defined}

The main areas for research and innovation for realization of the strategy for energy planning and energy efficiency in smart city areas are the following:

- shift the emphasis in the mechanisms of solving urban problems to self-organization, communication, strengthening of self-government, search for innovative solutions, achieving public consensus;

- create a "digital city" with maximum data openness, access to information, formation of intelligent self-management systems, reduce the costs of access to information $[13,14]$.

The logical scheme of the project which is aimed on realization of the strategy for energy planning and energy efficiency in smart city areas is presented at the Table 1.

Table 1. Logical scheme of the project

\begin{tabular}{|c|c|c|}
\hline Tasks $(\mathrm{T})$, subtasks $(\mathrm{ST})$ & The goal and outcomes & The method \\
\hline $\begin{array}{l}\text { T1. Social engagement and cohesion } \\
\text { ST1.1. Identification of the key } \\
\text { stakeholders } \\
\text { ST1.2. Introduction and presentation } \\
\text { of the key goals to decision makers } \\
\text { with the support of the key supporters } \\
\text { and local communities } \\
\text { ST1.3. Preparation of the key } \\
\text { challenges and the possible strategies } \\
\text { of communication to the local } \\
\text { communities } \\
\text { ST1.4. Promotion of the digitalization } \\
\text { approach to district energy supply } \\
\text { system among key stakeholders }\end{array}$ & $\begin{array}{l}\text { Reinforcement of local } \\
\text { leaders. } \\
\text { To recognize local/regional } \\
\text { leaders, potential key } \\
\text { local/regional supporters } \\
\text { which will facilitate the } \\
\text { communication within the } \\
\text { community. Recognition of } \\
\text { the potential for the project } \\
\text { idea. An agenda of } \\
\text { communication with local } \\
\text { communities, a local } \\
\text { working group based on the } \\
\text { members of community and } \\
\text { partners. Municipalities and } \\
\text { other stakeholders } \\
\text { empowered to become key } \\
\text { actors in the promotion of } \\
\text { digitalization of district }\end{array}$ & $\begin{array}{l}\text { Meetings, local } \\
\text { workshops, } \\
\text { study trips, } \\
\text { transnational } \\
\text { meetings, } \\
\text { panels and } \\
\text { workshops } \\
\text { between } \\
\text { partners. }\end{array}$ \\
\hline
\end{tabular}




\begin{tabular}{|c|c|c|}
\hline & energy system. & \\
\hline $\begin{array}{l}\text { T2. Selection of pilot districts for } \\
\text { energy improvement } \\
\text { ST2.1. Development of criteria and } \\
\text { selection of objects for piloting } \\
\text { ST2.2. Identification and analysis of } \\
\text { barriers and factors for success in } \\
\text { energy planning } \\
\text { ST2.3. Involvement of public } \\
\text { property owners and energy utilities }\end{array}$ & $\begin{array}{l}\text { Energy improvement } \\
\text { districts to be defined. } \\
\text { Concepts and approaches for } \\
\text { pilot district including } \\
\text { energy utilities and public } \\
\text { property owners. }\end{array}$ & $\begin{array}{l}\text { Workshops, } \\
\text { study visits, } \\
\text { questioning and } \\
\text { stakeholder } \\
\text { analysis. }\end{array}$ \\
\hline $\begin{array}{l}\text { T3. Digitalization of district energy } \\
\text { system for increasing energy } \\
\text { efficiency } \\
\text { ST3.1. Preparation of access points } \\
\text { for digitalization of district heating } \\
\text { ST3.2. Data collection through pilot } \\
\text { testing under specific local conditions } \\
\text { ST3.3. Analysis of collected data and } \\
\text { allocation of district energy resources } \\
\text { based on real demand } \\
\text { ST4. District level cooperation model } \\
\text { for local and regional authorities } \\
\text { ST5. ICT tools development }\end{array}$ & $\begin{array}{l}\text { To establish accompanying } \\
\text { research for testing pilots in } \\
\text { digitalization for increasing } \\
\text { energy efficiency } \\
\text { Scientific research on legal } \\
\text { framework for digital } \\
\text { solutions and on } \\
\text { implementation of digital } \\
\text { solutions for energy } \\
\text { resources use including } \\
\text { interfaces to renewable } \\
\text { energies. Data base with at } \\
\text { least } 3 \text { years data from at } \\
\text { least } 5 \text { access points ready } \\
\text { for analysis. New ICT-based } \\
\text { tools for involving citizens } \\
\text { and property users in } \\
\text { energy planning. The set of } \\
\text { models (district energy smart } \\
\text { greed, big data in district } \\
\text { heating systems, motivation } \\
\text { and behavior of consumers } \\
\text { and stakeholders in district } \\
\text { energy system). }\end{array}$ & $\begin{array}{l}\text { Technical } \\
\text { monitoring, } \\
\text { best practice } \\
\text { analysis, } \\
\text { Big Data } \\
\text { analysis, } \\
\text { imitation } \\
\text { modeling. }\end{array}$ \\
\hline
\end{tabular}

Source: Authors.

\section{Discussion}

Cities play a key role in reaching energy efficiency targets, but still face major challenges to achieve sufficient energy efficiency. Almost 50\% of the entire energy is used for heating or cooling, and buildings account for around $40 \%$ of energy consumption [12]. The existing building stock and infrastructures in cities have a great impact on final energy consumption [15].

Approximately $75 \%$ of the Europe population live in cities and urban areas and they concentrate the largest share of current energy consumption. To face this situation, we suggest to pass from a supply-oriented market to one determined by demand, transnational awareness and social impacts. In order to do so, energy production, storage and consumption need to be customized (vertical principle) and harmonized (horizontal principle); in this sense, digitalization represents an excellent opportunity for data analysis, efficient energy allocation and reduction of $\mathrm{CO} 2$ emissions. 
Individual behavior of citizens as energy consumers also plays a decisive role in improving the energy efficiency of cities. Modern approaches focus mainly on finding technical solutions that can't use the energy potential arising from behavioral changes. At the same time, according to date of the European Environment Agency, up to $20 \%$ of energy can be achieved through measures aimed at changing individual behavior. Therefore, the behavioral perspective should be an integral part of the approaches to improving energy efficiency. They must take into account the capabilities and needs of end users and involve energy users in the processes of energy planning, decision making and implementation.

\section{Conclusion}

The above measures for energy planning and energy efficiency in smart city areas focuses on the energy consumption of district energy systems including all Quadruple Helix stakeholders. With sensors installed in the regional grid and the connected buildings, collected digital data are used for control of energy supply system, and with predefined algorithms optimizes the whole energy system based on real demand. By using the virtual thermal inertia of the buildings, heat and energy can be saved without any change in the indoor temperature.

\section{References}

1. Assembly UN General "The Future we want (Resolution adopted by the General Assembly on 27 July 2012)" 53 [online]. Available at: http://www.undocuments.net/our-common-future.pdf (The United Nations, 2012)

2. Project 2011-091-SE693 Efficient Energy Management-EFEM [online]. Available at: http://acea.spb.ru/efem/www/ (2014)

3. Boverket's building regulations - mandatory provisions and general recommendations, BBR. BFS 2011: 6, with amendments up to BFS 2016: 6 [online]. Available at:

https://www.boverket.se/globalassets/publikationer/dokument/2016/boverketsbuilding-regulations--mandatory-provisions-and-general-recommendations-bbr-23.pdf $\underline{(2016)}$

4. E. Sussman, Reshaping municipal and county laws to foster green building, energy efficiency, and renewable energy. NYU Environmental Law Journal, 16, 1, (2008)

5. T. Van Der Schoor, B. Scholtens, Power to the people: local community initiatives and the transition to sustainable energy. Renewable and Sustainable Energy Reviews, 43, 666-675, (2015)

6. J. S. Nilsson, A. Mårtensson, Municipal energy-planning and development of local energy-systems. Applied Energy, 76(1-3), 179-187, (2003)

7. J. Palm, Development of sustainable energy systems in Swedish municipalities: A matter of path dependency and power relations. Local Environment, 11(4), 445-457, (2006)

8. C. Brandoni, F. Polonara, The role of municipal energy planning in the regional energy-planning process. Energy, 48(1), 323-338, (2012)

9. Strategy of economic and social development of St. Petersburg until 2030 [online]. Available at: 
http://cedipt.spb.ru/media/acts/2015/12/09/Strategy_of_economic_and_social_develop ment_of_St._Petersburg_until_2030.pdf (2018)

10. European Union (EU). Energy Efficiency [online]. Available at: https://ec.europa.eu/energy/en/topics/energy-efficiency (2017)

11. D. Popescu, S. Bienert, C. Schützenhofer, R. Boazu, Impact of energy efficiency measures on the economic value of buildings. Applied Energy, 89, 454-463, (2012)

12. G. Escriva-Escriva, Basic actions to improve energy efficiency in commercial buildings in operation. Energy and Buildings, 43, 3106-3111, (2011)

13. V. V. Glukhov, I. V. Ilin, A. B. Anisiforov, Problems of data protection in industrial corporations enterprise architecture. Proceedings of the 8th International Conference on Security of Information and Networks, 34-37, (2015)

14. V. V. Glukhov, I. V. Ilin, O. Y. Iliashenko, Improving the efficiency of architectural solutions based on cloud services integration. Lecture Notes in Computer Science, 9870, 512-524, (2016)

15. J. Parasonis, A. Keizikas, Increasing energy efficiency of the translucent enclosure walls of a building. Procedia Engineering, 57, 869-875, (2013) 